\title{
KINERJA GURU SMK WERDHI SILA KUMARA GIANYAR TAHUN 2017
}

\author{
Apuk Wijaya $^{1}$, lyus Ahmad Haris ${ }^{2}$, Lulup Endah Tripalupi ${ }^{3}$ \\ Jurusan Pendidikan Ekonomi \\ Universitas Pendidikan Ganesha \\ Singaraja, Indonesia \\ e-mail: apuk.wijaya@icloud.com¹,iyus.haris@gmail.com², \\ lulup_tripalupi@yahoo.com ${ }^{3}$
}

\begin{abstract}
Abstrak
Penelitian ini bertujuan untuk mendeskripsikan kinerja guru di SMK Werdhi Sila Kumara Gianyar yang ditinjau dari empat kompetensi yaitu, pedagogik, kepribadian, sosial, dan profesional. Penelitian ini menggunakan rancangan deskriptif kualitatif. Populasi dalam penelitian ini adalah seluruh guru yang bertugas di SMK Werdhi Sila Kumara Gianyar yang berjumlah 91 guru dan sampel yang digunakan dalam penelitian ini adalah seluruh populasi yang berjumlah 91 guru. Data dikumpulkan dengan menggunakan metode dokumentasi. Analisis data yang digunakan yaitu model analisis Miles dan Huberman, dan analisis Triangulasi data. Hasil penelitian ini menunjukkan bahwa, kinerja guru ditinjau dari kompetensi pedagogik terdapat 62 (68\%) guru dikategorikan sangat baik dan 29 (32\%) guru dikategorikan baik. Kinerja guru ditinjau dari kompetensi kepribadian terdapat 69 (76\%) guru dikategorikan sangat baik dan 22 (24\%) guru dikategorikan baik. Kinerja guru ditinjau dari kompetensi sosial terdapat 67 (74\%) guru dikategorikan sangat baik dan 24 (26\%) guru dikategorikan baik. Kinerja guru ditinjau dari kompetensi profesional terdapat $32(35 \%)$ guru dikategorikan sangat baik dan 59 (65\%) guru dikategorikan baik.
\end{abstract}

Kata kunci: kinerja guru, kompetensi pedagogik, kompetensi kepribadian, kompetensi sosial, kompetensi profesional.

\begin{abstract}
This study aims to describe the porformance of teachers SMK Werdhi Sila Kumara Gianyar in terms of four competencies that is, pedagogic, personality, social, and professional. This research uses qualitative descriptive design. Population in this study were all teachers who served in SMK Werdhi Sila Kumara Gianyar which amounted to 91 teachers and the sample used in this study is the entire population of 91 teachers. Data were collected using documentation method. Data analysis used is the analysis model Miles and Huberman, and data Triangulation analysis. The results of this study show that, teacher performance in terms of pedagogic competence there are 62 (68\%) teachers categorized excellent and 29 (32\%) teachers are categorized well. Teacher performance in terms of personality competence there are 69 (76\%) teachers categorized excellent and 22 (24\%) teachers are categorized well. Teacher performance in terms of social competence there are 67 (74\%) teachers categorized excellent and 24 (26\%) teachers are categorized well. Teacher performance in terms of professional competence there are 32 (35\%) teachers categorized excellent and 59 (65\%) teachers are categorized well.
\end{abstract}

Keywords: performance of teacher, pedagogic competence, personality competence, social competence, professional competence. 


\section{PENDAHULUAN}

Kinerja guru mempunyai

spesifikasi/kriteria kompetensi yang harus dimiliki setiap guru. Menurut Muhlisin (2008) guru merupakan faktor yang sangat dominan dan paling penting dalam pendidikan formal. Secara umum Peraturan Menteri Pendayagunaan Aparatur Negara dan Reformasi Birokrasi Nomor 16 Tahun 2009 Menjelaskan tugas utama guru adalah mendidik, mengajar, membimbing, mengarahkan, melatih, menilai, dan mengevaluasi peserta didik pada pendidikan anak usia dini jalur pendidikan formal, dasar, dan pendidikan menengah serta tugas tambahan yang relevan dengan fungsi sekolah. Pada umumnya bagi peserta didik, guru seringkali dijadikan tokoh teladan dan bahkan menjadi tokoh panutan dikelas maupun diluar kelas (lingkungan sekolah). Keberhasilan penyelenggaraan pembelajaran sangat ditentukan oleh kesiapa guru dalam mempersiapkan peserta didik yang konsisten melalui kegiatan belajar mengajar. Sebagai tenaga pendidik yang profesional guru dipersyaratkan untuk memiliki kualifikasi akademik S-1 atau D-4 dalam bidang yang relevan dengan mata pelajaran yang diampunya. Selain itu seorang guru dituntut memiliki kualfikasi akademik dengan mata pelajaran yang diampunya. Guru yang telah memiliki persyarakan kualifikasi akademik minimal dan menguasai kompetensi diharapkan dapat menunjukkan kinerja yang lebih optimal. Oleh karena itu untuk meningkatkan mutu pembelaaran maka dapat dipengaruhi oleh kompetensi yang dimiliki oleh guru. Kopentsi guru sebagaimana tercantum dalam Penjelasan Peraturan Menteri Pendidikan Nasional Republik Indonesia No. 16 Tahun 2007 tentang Standar Kualifikasi Akademik dan Kompentesi Guru. Standar kompetensi guru yang dikembangkan dari empat kompetensi utama yang dimaksud yaitu, kompetensi petagogik,kompetensi kepribadian, kompetensi sosial, dan kompetensi profesional. Kompetensi pedagogik merupakan kemampuan seorang guru dalam memahami karateristik atau kemampuan yang dimiliki oleh peserta didik melalui berbagai cara yang salah satunya melalui perkembagan kognitif dan merancang program pembelajaran dan pelaksanaan pembelajaran serta mengevaluasi sistem pembelajaran. Kompetensi kepribadian merupakan salah satu kemampuan personal yang harus dimiliki guru profesional dengan cara mencerminkan kepribadian yang baik pada diri sendiri, bersikap bijaksana dan berwibawa. Kompetensi sosial merupakan salah satu kompetensi yang harus dimiliki oleh seorang guru melalui cara yang baik dalam berkomunikasi dengan peserta didik dan seluruh tenaga kependidikan di Ingkungan sekolah. Kompetensi profesional merupakan kemampuan yang dimiliki guru dalam hal menguasai materi pembelajaran secara luas dan mendalam.

Guru sebagai salah seorang pelaksana kegiatan pendidikan harus menguasai keempat kompetensi diatas apabila seorang guru sudah menguasai keempat kompetensi maka diharapkan dapat memiliki kinerja yang baik. Menurut Sudarwan Danim (2011:111), "kinerja cenderung dipersepsikan sebagai tampilan riil di dunia kerja". Sulistyorini (dalam Muhlisin, 2008) mengatakan bahwa kinerja adalah tingkat keberhasilan seseorang atau kelompok orang dalam melaksanakan tugas dan tanggung jawabnya serta kemampuan untuk mencapai tujuan dan standar yang telah ditetapkan. Muhlisin lebih menspesifikasikan tentang pengertian kinerja yaitu sebagai hasil kerja yang dapat dicapai oleh seseorang atau sekelompok orang dalam suatu organisasi sesuai dengan wewenang dan tanggung jawab dalam rangka mencapai tujuan organsasi bersangkutan secara legal, tidak melanggar hukum dan sesuai degan moral dan etika. Menurut Munir (2008:31), "kinerja adalah hasil kerja berdasarkan penilaian tentang tugas dan fungsi jabatan sebagai pendidik, manajer lembaga pendidikan, administrator, supervisor, innovator, dan motivator atau apa pun yang penilaiannya dilaksanakan oleh suatu institusi tertentu". Kinerja bukan sekedar hasil yang terjadi setelah seseorang melaksanakan pekerjaannya, 
tetapi termasuk bagaimana proses pekerjaan tersebut dilaksanakan (Wibowo, 2012). Menurut Wahyudi (2012:128), "kinerja guru merupakan hasil kerja nyata secara kualitas dan kuantitas yang dicapai seorang guru dalam melaksanakan tugasnya sesuai dengan tanggung jawab yang diberikan kepadanya yang meliputi menyusun program pembelajaran, pelaksanaan pembelajaran, pelaksanaan evaluasi dan analisis dari evaluasi". Selain itu, kinerja juga dapat diartikan sebagai suatu hasil dan usaha seseorang yang dicapai dengan adanya kemampuan dan perubahan dalam situasi tertentu.

Kinerja guru tidak terbentuk dengan begitu saja, tetapi dipengaruhi oleh faktor-faktor tertentu. Barnawi (2012:43) menyatakan, "kinerja dapat dipengaruhi oleh dua faktor, yaitu faktor internal dan faktor eksternal. Faktor internal menyangkut tentang faktor yang ada dalam diri guru dan dapat mempengaruhi kinerjanya seperti kemampuan, keterampilan, kepribadian, persepsi, motivasi menjadi guru, pengalaman lapangan, dan latar belakang keluarga. Sedangkan faktor eksternal adalah faktor yang datang dari luar guru yang dapat mempengaruhi kinerja guru, seperti gaji, sarana dan prasarana, lingkungan kerja dan kepemimpinan.

Kinerja guru dapat dilihat dari tampilan nyata guru sehari-hari dalam pelaksanaan tugas dan fungsinya. Tugas dan fungsi yang dilaksanakan oleh guru merupakan bentuk realisasi nyata dalam pelaksanaan tanggung jawab dan profesionalitasnya sebagai seorang guru. Tugas, peran dan fungsi guru merupakan satu kesatuan yang utuh. Tugas dan fungsi yang dilaksanakan seorang guru merupakan bentuk penjabaran dari peran guru dalam masyarakat tetap dominan sekalipun teknologi yang dapat dimanfaatkan dalam pembelajaran berkembang sangat cepat. Hal ini disebabkan karena ada dimensi-dimensi proses pendidikan, atau lebih khusus bagi proses pembelajaran, yang diharapkan oleh guru yang tidak dapat digantikan oleh teknologi.

Menurut Sanjaya (2006) peran guru, yaitu, guru sebagai sumber belajar, guru sebagai fasilitator, guru sebagai pengelola, guru sebagai demonstrator, guru sebagai pembimbing, guru sebagai motivator, dan guru sebagai evaluator.

Dalam dunia pendidikan kinerja guru sangat penting untuk diperhatikan dan dievaluasi karena guru mengemban tugas profesional artinya tugas-tugas hanya dapat dikerjakan dengan kompetensi khusus yang diperoleh melalui program pendidikan. Kinerja guru yang ditunjukan dapat diamati dari kemampuan guru dalam melaksanakan tugas dan tanggung jawabnya yang tentunya sudah dapat mencerminkan suatu pola kerja yang dapat meningkatkan mutu pendidikan kearah yang lebih baik. Kinerja seseorang dapat ditingkatkan bila terdapat kesesuaian antara pekerjaan dengan keahliannya, begitu pula halnya dengan penempatan guru pada bidang tugasnya. Menurut Muhlisin (2008:27), "bahwa menempatkan guru sesuai dengan keahliannya secara mutlak harus dilakukan". Bila guru melakukan tugas tidak sesuai dengan keahliannya akan berakibat menurunnya cara kerja dan hasil pekerjaan mereka, juga akan menimbulkan rasa tidak puas pada diri mereka. Rasa kecewa akan menghambat perkembangan moral kerja guru.

Dalam upaya mewujudkan kinerja yang baik diperlukan penilaian kinerja. Penilaian kinerja guru diartikan sebagai penilaian dari tiap butir kegiatan tugas utama guru dalam kerangka pembinaan karir kepangkatan dan jabatannya. Hasibuan (2007) memberikan pengertian tentang penilaian kinerja guru sebagai suatu bahan evaluasi terhadap perilaku, prestasi kerja, dan potensi pengembangan yang telah dilakukan. Wahyudi (2012) juga berpendapat bahwa penilaian kinerja ditujukan untuk mengetahui seberapa besar mereka bekerja melalui suatu sistem formal dan terstruktur, seperti menilai, mengukur, dan mempengaruhi sifat-sifat yang berkaitan dengan pekerjaan, perilaku, dan hasil, termasuk tingkat ketidakhadiran. Hasil penilaian kinerja ini dapat digunakan untuk mengetahui produktivitas kerja seseorang 
sehingga pemimpin dapat mengambil keputusan dari hasil penilaian tersebut. Menurut Peraturan Menteri Negara Pendayagunaan Aparatur Negara dan Reformasi Birokrasi Nomor 16 Tahun 2009 Pasal 15 ayat 1, penilaian kinerja guru adalah penilaian yang dilakukan terhadap setiap butir kegiatan dari sub unsur pembelajaran atau pembimbingan dan tugas tambahan yang relevan didasarkan atas aspek kualitas, kuantitas, waktu dan biaya. "Penilaian kinerja guru pada dasarnya merupakan proses membandingkan antara kinerja aktual dengan kinerja ideal untuk mengetahui tingkat keberhasilan guru dalam melaksanakan tugas-tugasnya dalam periode tertentu" (Barnawi, 2012:25). Hasil penilaian kinerja dapat dijadikan dasar untuk menentukan kebijakan dalam hal promosi jabatan dan pemberian imbalan. Aspek-aspek yang dinilai dalam penilaian kinerja guru harus sesuai dengan apa yang harus dikerjakan oleh guru. Penilaian kinerja guru diharapkan dapat meningkatkan kinerja guru yang pada akhirnya mewujudkan sosok guru yang profesional.

Sekolah Menengah Kejuruan (SMK) Werdhi Sila Kumara Gianyar adalah sekolah kejuruan pada bidang keahlian pariwisata. Sekolah ini berstatus sekolah swasta yang bernaung dibawah Yayasan Werdhi Sila Kumara. Lembaga pendidikan menengah ini memiliki tenaga pendidik (guru) sebanyak 91 orang. Hasil pengamatan dilapangan menunjukkan bahwa secara umum keadaan guru tersebut dilihat dari jenjang pendidikannya sudah cukup baik, karena pada umumnya guru di SMK Werdhi Sila Kumara Gianyar sudah memiliki jenjang pendidikan strata satu. Untuk mengukur kinerja guru tersebut diperlukan sebuah penilaian dan penilaian yang digunakan adalah penilaian kinerja guru di SMK Werdhi Sila Kumara Gianyar. Berdasarkan uraian tersebut, dirasa sangat penting untuk menguji lebih lanjut tentag bagaimana kinerja guru di SMK Werdhi Sila Kumara Gianyar dan menjadi dasar penelitian yang berjudul Kinerja Guru SMK Werdhi Sila Kumara Tahun 2017.

\section{METODE}

Jenis penelitian ini adalah penelitian deskriptif kualitatif. Rancangan deskripstif kualitatif digunakan untuk memperoleh gambaran yang jelas, objektif, sistematis, dan cermat mengenai fakta-fakta aktual dari sifat populasi. Rancangan ini digunakan sebagai prosdur mengidentifikasi dan mendeskripsikan fenomena yang terdapat di dalam sumber data tanpa rekayasa. Dalam penelitian ini, mendeskripsikan tentang kinerja guru SMK Werdhi Sila Kumara Gianyar. Penelitian ini dilakukan pada Sekolah Menengah Kejuruan (SMK) Werdhi Sila Kumara Gianyar. SMK Werdhi Sila Kumara Gianyar adalah sekolah kejuruan pada bidang keahlian pariwisata. Sekolah ini berstatus sekolah swasta yang dikelola oleh Yayasan Werdhi Sila Kumara.

Populasi dalam penelitian ini adalah seluruh guru yang bertugas di SMK Werdhi Sila Kumara Gianyar yang berjumlah 91 guru. Melihat jumlah populasi dalam penelitian yang berjumlah 91 guru, maka sampel yang digunakan dalam penelitian ini adalah seluruh populasi. Jadi sampel dalam penelitian ini adalah total populasi yang berjumlah 91 guru. Penelitian ini mengkaji kinerja guru yang di tinjau dari empat kompetensi yang terdiri dari kompetensi pedagogik, kompetensi kepribadian, kompetensi sosial, dan kompetensi profesional.

Tabel 1. Kategori penilaian

\begin{tabular}{cll}
\hline No. & Keterangan & Presentase \\
\hline 1 & Sangat Buruk & $0-25 \%$ \\
2 & Buruk & $26-50 \%$ \\
3 & Baik & $50-75 \%$ \\
4 & Sangat Baik & $76-100 \%$ \\
\hline
\end{tabular}

(Sumber: Permenegpan dan RB No. 16 Tahun 2009 tentang Jabatan Fungsional Guru dan Angka Kreditnya).

Berdasarkan tabel 1 diatas menunjukkan bahwa penilaian kinerja guru menggunakan presentase berdasarkan Permenegpan dan Reformasi Birokrasi Nomor 16 Tahun 2009 tentang Jabatan Fungsional Guru dan Angka Kreditnya. 
Dalam penelitian ini metode yang digunakan adalah metode dokumentasi. Peneliti menggunakan metode deskriptif kualitatif sebagai metode analisis data. Analisis data dalam penelitian ini menggunakan prosedur dengan model pemeriksaan keabsahan data yaitu teknik triangulasi data. Menurut Moleong (2012:330) triangulasi adalah teknik pemeriksaan keabsahan data yang memanfaatkan sesuatu yang lain di luar data yang diperoleh untuk keperluan pengecekan atau sebagai pembanding terhadap data yang diperoleh. Dalam penelitian ini peneliti menggunakan teknik pemeriksaan keabsahan data triangulasi dengan sumber. Moleong (2012:331) triangulasi dengan sumber "berarti membandingkan dan mengecek balik derajat kepercayaan suatu informasi yang diperoleh melalui waktu dan alat yang berbeda dalam penelitian kualitatif". Penggunaan teknik triangulasi dengan sumber, peneliti membandingkan hasil wawancara yang diperoleh dari masing- analisis Miles dan Huberman (dalam Sugiyono, 2007:337) yang meliputi, reduksi data, penyajian data, dan penarikan simpulan/verifikasi. Selain itu peneliti juga menggunakan teknik

masing sumber atau informan penelitian sebagai pembanding untuk mengecek kebenaran informasi yang didapatkan.

\section{HASIL DAN PEMBAHASAN}

Berdasarkan hasil penilaian kinerja guru SMK Werdhi Sila Kumara Gianyar yang ditinjau dari kompetensi pedagogik yang dinilai dari indikator kompetensi yaitu, menguasai karakteristik peserta didik, menguasai teori belajar, dan prinsipprinsip pembelajaran yang mendidik dan mendukung pembelajaran peserta didik, mengembangkan kurikulum pendidikan, kegiatan pembelajaran yang mendidik dan mendukung, pengembangan potensi peserta didik, komunikasi dengan pesrta didik, menilai dan evaluasi, hasil penilaian kinerja guru dapat dilihat dalam tabel 2 .

Tabel 2. Kinerja guru SMK Werdhi Sila Kumara ditinjau dari kompetensi pedagogik

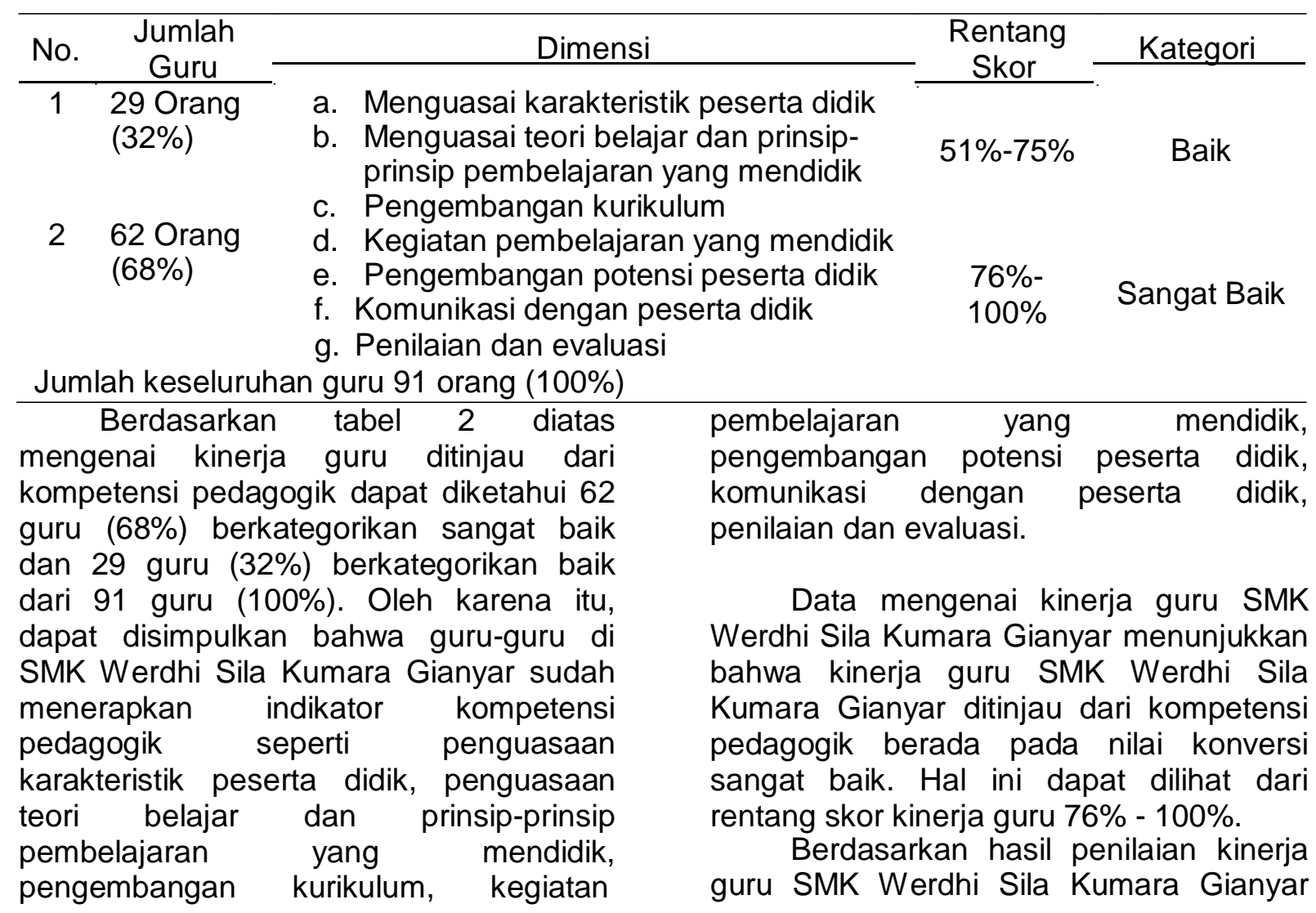


yang ditinjau dari kompetensi kepribadian jawab yang tinggi, rasa bangga menjadi

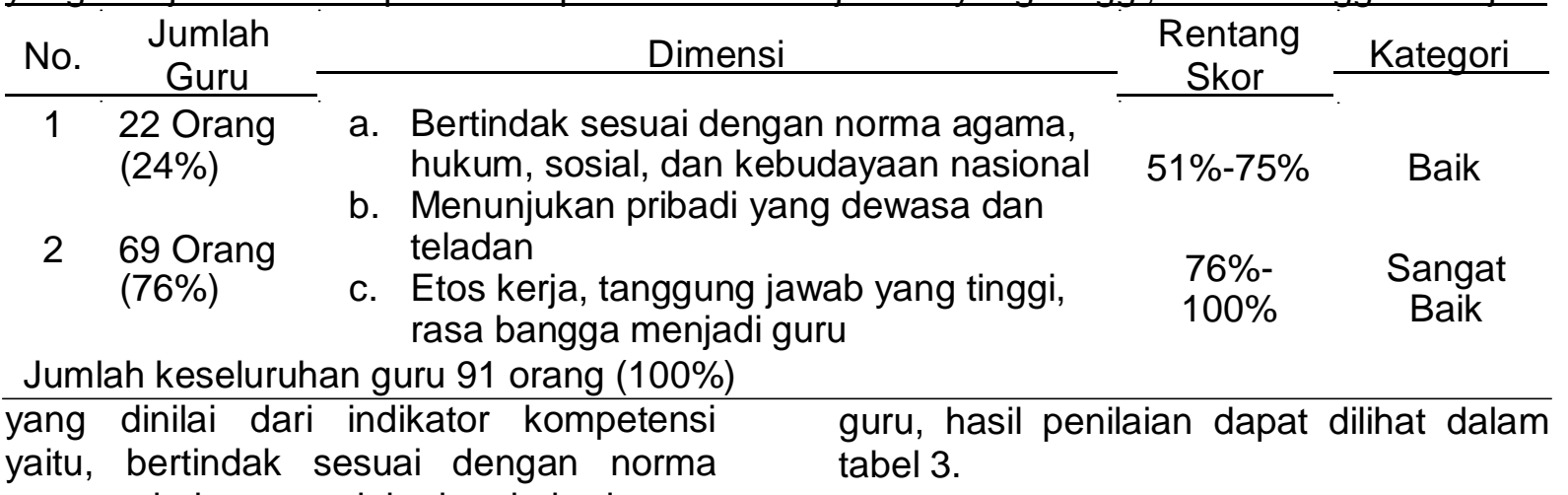
agama, hukum, sosial, dan kebudayaan nasional, menunjukan pribadi yang Tabel 3. Kinerja guru SMK Werdhi Sila Kumara ditinj dewasa dan teladan, etos kerja, tanggung

Berdasarkan tabel 3 diatas mengenai kinerja guru ditinjau dari kompetensi kepribadian dapat diketahui 69 guru (76\%) berkategorikan sangat baik dan 22 guru (24\%) berkategorikan baik dari 91 guru (100\%). Oleh karena itu, dapat disimpulkan bahwa guru-guru di SMK Werdhi Sila Kumara Gianyar sudah menerapkan indikator kompetensi kepribadian.

Data mengenai kinerja guru SMK Werdhi Sila Kumara Gianyar menunjukkan bahwa kinerja guru SMK Werdhi Sila Kumara Gianyar ditinjau dari kompetensi kepribadian berada pada nilai konversi sangat baik. Hal ini dapat dilihat dari rentang skor kinerja guru $76 \%-100 \%$.

Berdasarkan hasil penilaian kineja guru SMK Werdhi Sila Kumara Gianyar yang ditinjau dari kompetensi sosial yang dinilai dari indikator kompetensi yaitu, bersikap inklusif, bertaindak obyektif, serta tidak diskriminatif, komunikasi dengan sesama guru, tenaga kependidikan, orang tua, peserta didik, dan masyarakat, tanggung jawab yang tinggi, rasa bangga menjadi guru, hasil penilaian dapat dilihat dalam tabel

Tabel 4. Kinerja guru SMK Werdhi Sila Kumara ditinjau dari kompetensi sosial

\begin{tabular}{|c|c|c|c|c|}
\hline No. & $\begin{array}{l}\text { Jumlah } \\
\text { Guru }\end{array}$ & Dimensi & $\begin{array}{c}\text { Rentang } \\
\text { Skor }\end{array}$ & Kategori \\
\hline 1 & $\begin{array}{l}24 \text { Orang } \\
(26 \%)\end{array}$ & $\begin{array}{l}\text { a. Bersikap inklusif, bertaindak obyektif, } \\
\text { serta tidak diskriminatif } \\
\text { b. Komunikasi dengan sesama guru, }\end{array}$ & $51 \%-75 \%$ & Baik \\
\hline 2 & $\begin{array}{l}67 \text { Orang } \\
(74 \%)\end{array}$ & $\begin{array}{l}\text { tenaga kependidikan, orang tua, peserta } \\
\text { didik, dan masyarakat, tanggung jawab } \\
\text { yang tinggi, rasa bangga menjadi guru }\end{array}$ & $\begin{array}{l}76 \%- \\
100 \%\end{array}$ & $\begin{array}{c}\text { Sangat } \\
\text { Baik }\end{array}$ \\
\hline
\end{tabular}

Jumlah keseluruhan guru 91 orang $(100 \%)$

Berdasarkan tabel 4 diatas mengenai kinerja guru ditinjau dari kompetensi sosial dapat diketahui 67 guru (74\%) berkategorikan sangat baik dan 24 guru (26\%) berkategorikan baik dari 91 guru $(100 \%)$. Oleh karena itu, dapat disimpulkan bahwa guru-guru yang bertugas di SMK Werdhi Sila Kumara Gianyar sudah sebagian besar

menerapkan indikator kompetensi
kepribadian.

Data mengenai kinerja guru SMK Werdhi Sila Kumara Gianyar menunjukkan bahwa kinerja guru di SMK Werdhi Sila

Kumara Gianyar ditinjau dari kompetensi sosial berada pada nilai konversi sangat baik. Hal ini dapat dilihat dari rentang skor kinerja guru $76 \%-100 \%$. 
Berdasarkan hasil penilaian kineja guru SMK Werdhi Sila Kumara Gianyar yang ditinjau dari kompetensi profesional yang dinilai dari indikator kompetensi yaitu, penguasaan materi, struktur, konsep, dan pola pikir keilmuan yang mendukung mata pelajaran yang diampu, mengembangkan keprofesionalan melalui tindakan yang reflektif, hasil penilaian dapat dilihat dalam tabel 5 .

Tabel 5. Kinerja guru SMK Werdhi Sila Kumara ditinjau dari kompetensi profesional

\begin{tabular}{|c|c|c|c|c|}
\hline No. & $\begin{array}{c}\text { Jumlah } \\
\text { Guru }\end{array}$ & Dimensi & $\begin{array}{c}\text { Rentang } \\
\text { Skor }\end{array}$ & Kategori \\
\hline 1 & $\begin{array}{l}59 \text { Orang } \\
(65 \%)\end{array}$ & $\begin{array}{l}\text { a. Penguasaan materi, struktur, konsep, } \\
\text { dan pola pikir keilmuan yang } \\
\text { mendukung mata pelajaran yang }\end{array}$ & $51 \%-75 \%$ & Baik \\
\hline Jun & $\begin{array}{l}32 \text { Orang } \\
(35 \%) \\
\text { ah keseluru }\end{array}$ & $\begin{array}{l}\text { diampu } \\
\text { b. Mengembangkan keprofesionalan } \\
\text { melalui tindakan yang reflektif } \\
\text { guru } 91 \text { orang }(100 \%)\end{array}$ & $\begin{array}{l}76 \%- \\
100 \%\end{array}$ & $\begin{array}{c}\text { Sangat } \\
\text { Baik }\end{array}$ \\
\hline
\end{tabular}

Berdasarkan tabel 5 diatas mengenai kinerja guru ditinjau dari kompetensi profesional dapat diketahui 32 guru $(35 \%)$ berkategorikan sangat baik dan 59 guru $(65 \%)$ berkategorikan baik dari 91 guru(100\%). Oleh karena itu, dapat disimpulkan bahwa guru-guru di SMK Werdhi Sila Kumara Gianyar belum sebagaian besar menerapkan indikator kompetensi profesional.

Data mengenai kinerja guru SMK Werdhi Sila Kumara Gianyar menunjukkan bahwa kinerja guru SMK Werdhi Sila Kumara Gianyar ditinjau dari kompetensi profesional berada pada nilai konversi baik. Hal ini dapat dilihat dari rentang skor kinerja guru $51 \%-75 \%$.

\section{Pembahasan}

Pencapaian kompetensi pedagogik guru dari 91 guru sudah melebihi 50\% dan hal tersebut menandai bahwa guru-guru di SMA Werdhi Sila Kumara Gianyar dalam mengajar telah menerapkan kompetensi pedagogik, sehingga kegiatan belajarmengajar di kelas menjadi baik dan kondusif.

dari Hasil penilaian kinerja guru ditinjau berkategorikan sangat baik terdapat 62 (68\%) guru dari 91 (100\%) guru. Guru dapat memperoleh penilaian sangat baik karena guru sudah memenuhi indikator kompetensi pedagogik seperti, menguasai karakteristik peserta didik, menguasai teori belajar dan prinsip-prinsip pembelajaran yang mendidik, pengembangan kurikulum pembelajaran yang mendidik, kegiatan pembelajaran yang mendidik, pengembangan potensi peserta didik, komunikasi dengan peserta didik, penilaian dan evaluasi.

Guru yang memperoleh hasil baik terdapat 29 (32\%) guru dari 91 (100\%) guru, tentunya belum sempurna menguasai indikator kompetensi pedagogik seperti, menguasai karakteristik peserta didik, menguasai teori belajar dan prinsip-prinsip pembelajaran yang mendidik, pengembangan kurikulum pembelajaran, kegiatan pembelajaran yang mendidik, pengembangan potensi peserta didik, komunikasi dengan peserta didik, dan penilaian dan evaluasi.

Tidak satupun dari 91 guru yang mendapatkan skor buruk ataupun sangat buruk. Karena sebagian besar guru sudah menguasai indikator kompetensi pedagogik berdasarkan Peraturan Menteri Pendidikan Nasional Nomor 16 Tahun 2007 tentang Standar Kualifikasi Akademi dan Kompetensi Guru yang di paparkan diatas dan sudah melaksanakan proses pembelajaran dengan baik juga sudah menerapkan pemahaman wawasan atau landasan kependidikan, pemahaman terhadap peserta didik, pengembangan kurikulum atau silabus, perancangan pembelajaran, pelaksanaan pembelajaran yang mendidik dan dialogis, pemanfaatan teknologi pembelajaran, evaluasi hasil belajar. Hal ini menyatakan bahwa kualitas kompetensi pedagogik guru yang 
mengajar di SMK Werdhi Sila Kumara Gianyar telah memenuhi syarat mengajar berdasarkan kompetensi pedagogik.

Pencapaian kompetensi kepribadian guru dari 91 guru sudah melebihi $50 \%$ dan hal tersebut menandai bahwa guru-guru di SMA Werdhi Sila Kumara Gianyar dalam mengajar telah menerapkan kompetensi kepribadian, sehingga kegiatan belajarmengajar di kelas menjadi baik dan kondusif.

Hasil penilaian kinerja guru ditinjau dari kompetensi kepribadian, berkategorikan sangat baik terdapat 69 (76\%) guru dari 91 (100\%) guru. Guru dapat memperoleh penilaian sangat baik karena guru sudah memenuhi indikator kompetensi kepribadian seperti, bertindak sesuai dengan norma agama, hukum, sosial, dan kebudayaan nasional, menunjukan pribadi yang dewasa dan teladan, etos kerja, tanggung jawab yang tinggi, rasa bangga menjadi guru.

Guru yang memperoleh hasil baik terdapat 22 (24\%) guru dari 91 (100\%) guru, tentunya belum sempurna menguasai indikator kompetensi kepribadian seperti, bertindak sesuai dengan norma agama, hukum, sosial, dan kebudayaan nasional, menunjukan pribadi yang dewasa dan teladan, etos kerja, tanggung jawab yang tinggi, rasa bangga menjadi guru.

Tidak satupun dari 91 guru yang mendapatkan skor buruk ataupun sangat buruk. Karena sebagian besar guru sudah menguasai indikator kompetensi kepribadian yang di paparkan diatas dan sudah melaksanakan proses pembelajaran dengan baik juga sudah bertindak sesuai dengan norma agama, menunjukan pribadi yang dewasa dan bertanggung jawab yang tinggi sebagai guru. Hal ini menyatakan bahwa kualitas kompetensi kepribadian guru yang mengajar di SMK Werdhi Sila Kumara Gianyar telah memenuhi syarat mengajar berdasarkan kompetensi kepribadian.

Pencapaian kompetensi sosial guru dari 91 guru sudah melebihi $50 \%$ dan hal tersebut menandai bahwa guru-guru di SMA Werdhi Sila Kumara Gianyar dalam mengajar telah menerapkan kompetensi sosial, sehingga kegiatan belajar- mengajar di kelas menjadi baik dan kondusif.

Hasil penilaian kinerja guru ditinjau dari kompetensi sosial, berkategorikan sangat baik terdapat 67 (74\%) guru dari $91(100 \%)$ guru. Guru dapat memperoleh penilaian sangat baik karena guru sudah memenuhi indikator kompetensi sosial seperti, bersikap inklusif, bertaindak obyektif, serta tidak diskriminatif, komunikasi dengan sesama guru, tenaga kependidikan, orang tua, peserta didik, dan masyarakat, tanggung jawab yang tinggi, rasa bangga menjadi guru.

Guru yang memperoleh hasil baik terdapat 24 (26\%) guru dari 91 (100\%) guru, tentunya belum sempurna menguasai indikator kompetensi kepribadian seperti, bersikap inklusif, bertaindak obyektif, serta tidak diskriminatif, komunikasi dengan sesama guru, tenaga kependidikan, orang tua, peserta didik, dan masyarakat, tanggung jawab yang tinggi, rasa bangga menjadi guru.

Tidak satupun dari 91 guru yang mendapatkan skor buruk ataupun sangat buruk. Karena sebagian besar guru sudah menguasai indikator kompetensi kepribadian seperti yang di paparkan diatas dan sudah melaksanakan proses pembelajaran dengan baik juga sudah bersikap inklusif, berkomunikasi sesama guru dan tenaga pendidik yang santun, dan memiliki tanggung jawab yang tinggi menjadi guru. Hal ini menyatakan bahwa kualitas kompetensi sosial guru yang mengajar di SMK Werdhi Sila Kumara Gianyar telah memenuhi syarat mengajar berdasarkan kompetensi sosial.

Pencapaian kompetensi profesional guru terlihat kurang dari $50 \%$ dari 91 guru dan hal tersebut menandai bahwa guruguru di SMA Werdhi Sila Kumara Gianyar dalam mengajar sebagian besar kurang menerapkan kompetensi profesional, sehingga kegiatan belajar-mengajar di kelas kurang kondusif.

Hasil penilaian kinerja guru ditinjau dari kompetensi profesional, berkategorikan sangat baik terdapat 32 $(35 \%)$ guru dari 91 (100\%) guru. Guru dapat memperoleh penilaian sangat baik karena guru sudah memenuhi indikator 
kompetensi profesional seperti, penguasaan materi, struktur, konsep, dan pola pikir keilmuan yang mendukung mata pelajaran yang diampu, mengembangkan keprofesionalan melalui tindakan yang reflektif.

Guru yang memperoleh hasil baik terdapat 59 (65\%) guru dari 91 (100\%) guru, tentunya belum sempurna menguasai indikator kompetensi kepribadian seperti, penguasaan materi, struktur, konsep, dan pola pikir keilmuan yang mendukung mata pelajaran yang diampu, mengembangkan keprofesionalan melalui tindakan yang reflektif.

Dari hasil wawancara dengan kepala sekolah belum maksimalnya guruguru di SMK Werdhi Sila Kumara Gianyar menerapkan indikator kompetensi profesional seperti yang dipaparkan di atas mengakibatkan hasil pencapaian kinerja guru sangat rendah. Hal ini menyatakan bahwa kualitas kompetensi profesional guru yang mengajar di SMK Werdhi Sila Kumara Gianyar belum sebagian besar memenuhi syarat mengajar.

Untuk memperkuat hasil penelitian ini, peneliti melakukan wawancara dengan kepala sekolah, tenaga kependidikan, dan peserta didik.

Hasil wawancara dengan kepala sekolah, menyatakan bahwa kinerja guru di SMK Werdhi Sila Kumara Gianyar sudah sangat baik dan guru sudah melaksanakan tugasnya dengan baik. Hal ini dapat dilihat dari kemampuannya dalam mengajar, komunikasi dengan warga sekolah (kepala sekolah, guru, tenaga kependidikan, peserta didik). Guru yang bertugas di sekolah ini rata-rata sudah melaksanakan hal tersebut dan kinerja guru di sekolah ini sudah sangat bagus tentunya. Di SMK Werdhi Sila Kumara Gianyar ini, guru mengajar sudah sesuai dengan keahlian bidang yang diajarkannya/diampunya. Apabila guru mengajar tidak sesuai dengan bidang keahliannya berakibatkan menurunnya cara kerja yang paling tepatnya adalah kenyamanan seorang guru untuk mendidik/mengajar itu kurang. Dapat dilihat dari cara pengelolaan kelas, ada guru yang sudah benar-benar mampu untuk melaksanakan tugas mendidik dan memberikan peserta didiknya pelatihan pembelajaran yang mendidik, ada juga guru yang belum sempurna atau belum begitu bagus guru melaksanakan tugas mendidiknya sehingga kelas tidak menjadi kondusif.

Dilihat dari kompetensi pedagogik guru, dapat diketahui pada saat kepala sekolah dan tim penilai yang sudah disertivikasi dan guru di SMK Werdhi Sila Kumara tentunya sudah $70 \%$ menguasai indikator seperti halnya, menguasai karakteristik peserta didik, menguasai teori belajar dan prinsip-prinsip pembelajaran yang mendidik, pengembangan kurikulum, kegiatan pembelajaran yang mendidik, pengembangan potensi peserta didik, komunikasi dengan peserta didik, penilaian dan evaluasi. Begitu juga dari kompetensi kepribadian dan kompetensi sosial guru juga bagus, namun yang belum begitu sempurna ialah dari kompetensi profesional. Jadi, guru yang mendidik di sekolah ini tentunya belum begitu sempurna menerapkan indikator kompetensi profesional.

Hasil wawancara dengan tenaga kependidikan, dapat diketahui bahwa kinerja guru yang bertugas disekolah ini $60 \%$ dari keseluruhan guru yang bertugas dapat dilihat begitu bagus, dan sisa $40 \%$ dapat dilihat sepertinya begitu kurang bagus. Dari $60 \%$ guru yang dikatakan oleh tenaga kependidikan yang bertugas di tata usaha SMK Werdhi Sila Kumara dilhat dari kedatangan yang begitu tepat waktu, absensi begitu rajin, dari tugas mendidik sangat bagus, dilihat dari kualitas kerja sangat bagus, dan cara berkomunikasi juga sangat sopan. Dari $40 \%$ guru dapat diketahui kinerjanya kurang bagus dikarenakan absensi, ketepatan dan kecepatan kerja kurang bagus. didik, dapat diketahui berkenaan pada saat jam istirahat pembelajaran, cara kerja guru (cara mengajar) di SMK Werdhi Sila Kumara Gianyar sangat bagus tetapi hanya sebagian guru, dikatakan sangat bagus oleh peserta didik karena absensi guru dikelas tetap hadir mengajar, selalu 
memberikan bimbingan dan pelatihan yang mendidik, dan dapat mengarahkan ke hal yang positif. Sebagian guru yang dikatakan kurang bagus atau kurang sempurna dikarenakan guru jarang hadir kekelas untuk mengajar, kurangnya menguasai teori pembelajaran, cara berkomunikasi dengan peserta didik dirasakan kurang.

Dapat didukung dan sejalan dengan penelitian yang dilakukan oleh Putra (2015) dari keseluruhan guru yang bertugas di sekolah tersebut terdapat 68 orang guru dan kinerja guru yang dilihat dari empat kompetensi guru di SMK N 1 Gianyar tergolong sangat baik.

\section{SIMPULAN DAN SARAN}

Ada empat simpulan yang dapat peneliti ambil berdasarkan hasil dan pembahasan penelitian. Kinerja guru Smk Werdhi Sila Kumara Gianyar ditinjau dari kompetensi pedagogik tergolong sangat baik, kinerja Guru Smk Werdhi Sila Kumara Gianyar ditinjau dari kompetensi kepribadian tegolong sangat baik, kinerja guru Smk Werdhi Sila Kumara Gianyar ditinjau dari kompetensi sosial tergolong sangat baik, kinerja guru Smk Werdhi Sila Kumara Gianyar ditinjau dari kompetensi profesional tergolong baik.

Berdasarkan paparan mengenai hasil penelitian, adapun saran-saran yang dapat disampaikan dalam penelitian ini adalaah sebagai berikut. Bagi Guru SMK Werdhi Sila Kumara Gianyar agar selalu memperhatikan empat kompetensi guru yang terdiri dari kompetensi pedagogik, kompetensi kepribadian , kompetensi sosial, kompetensi profesional yang menunjang profesi guru dengan cara, meningkatkan kompetensi guru melalui pelatihan, meningkatkan kompetensi guru melalui penelitian tindakan kelas, dan meningkatkan kompetensi guru melalui sumber belajar.

Bagi sekolah hasil penelitian ini tentunya dapat dipergunakan sebagai output/masukan dalam meningkatkan kinerja guru SMK Werdhi Sila Kumara Gianyar.

\section{DAFTAR PUSTAKA}

Barnawi, Mohammad Arifin, 2012 Kinerja Guru Profesional. Yogjakarta: Ar-Ruz Media.

Danim, Sudarwan. 2011. Pengembangan Profesi Guru Dari Pra-Jabatan, Induksi Ke Profesional Madani. Jakarta: Kencana Media Group.

Putra, M.K. 2015. Pengaruh Persepsi Guru Tentang Gaya Kepemimpinan Kepala Sekolah Dan Iklim Kerja Terhadap Kinerja Guru Smk N 1 Gianyar Tahun Pelajaran 2014/2015. Skripsi tidak diterbitkan. UNDIKSHA.

Hasibuan, Malayu. 2007. Manajemen Sumber Daya Manusia. Jakarta: Bumi Aksara.

Moleong, Lexy. 2012. Metodologi Penelitian Kualitatif. Bandung: Remaja Rosdakarya.

Muhlisin. 2008. "Profesionalisme Kinerja Guru Masa Depan" Tersedia pada https://muhlis.files.wordpress.com/ 2008/05/profesionalisme-kinerjaguru-masa-depan.doc (Diakses tanggal 20 agustus 2017).

Munir, Abdulah. 2008. Menjadi Kepala Sekolah Efektif. Yogyakarta: ARRUZZ MEDIA.

Peraturan Menteri Negara Pendayagunaan Aparatur Negara dan Reformasi Birokrasi Nomor 16 Tahun 2009.

Peraturan Menteri Pendidikan Nasional Republik Indonesia Nomor 16 Tahun 2007 Tentang Standar Kualifikasi Akademik Dan Kompetens Guru. Jakarta: Direktorat Tentang Kependidikan Depdiknas.

Sanjaya, Wina. 2006. Strategi Pembelajaran Berorientasi Standar Proses Pendidikan. Jakarta: Kencana Prenada Media Group.

Sugiyono. 2007. Metode Penelitian Pendidikan (Pendekatan Kuantitatif, Kualitatif, dan $R \& D)$. Bandung: Alfabeta. 
Wahyudi. 2012. Pengembangan Pendidikan. Jakarta: PT. Prestasi Pustakaraya.

Wibowo. 2012. Manajemen Kinerja. Jakarta: Rajawali Pers. 